Coast and Geodetic Survey. Among the various interesting topics dealt with, is the remarkable submerged canyon of the Hudson River, about fifty miles at sea off the entrance to New York Harbour. This great gorge, approaching in magnitude the Grand Canyon of the Colorado, is at one place more than $2400 \mathrm{ft}$. deep, and three miles wide from rim to rim; it is about twenty miles long, and at its opening spreads out fan-like. It is of use during fog, as a 'seamark' for vessels equipped with sound-echo apparatus. Springs welling up in the sea are also described, both water springs and oil springs. One of the former, off the Florida coast, sends up millions of gallons of fresh mineral water from a hole about $25 \mathrm{ft}$. in diameter and $70 \mathrm{ft}$. deep in the ocean bed, itself $50 \mathrm{ft}$. deep; the water springs up with considerable force, so that it is difficult to hold a boat over it, and it has a sulphurous smell. Elsewhere; off Alaska, the sea-bottom sounding lead, 'armed' with tallow, shows gold dust as a bottom characteristic ; but the depth is too great to permit of dredging. 0ther remarkable ocean features off Alaska are pinnacle rocks, often extending to within a few feet of the surface, which are the cause of many shipwrecks : and a submarine volcano, rising from a depth of nearly $6000 \mathrm{ft}$., which throws up islands and blasts them again with violent explosions, nearly every year witnessing some change in the appearance of the island.

\section{Preservation of Chillingham Cattle}

THE appeal, to which reference has been made (Nature, Feb. 13, p. 241), has now been issued by the Zoological Society of London. Recognising the particular interest of the famous herd of white park cattle at Chillingham Castle, and the impossibility of its maintenance, under present financial conditions, by the owner, the Earl of Tankerville, the Council has taken a lease of the Park for seven years at a rental of $£ 500$ annually. Of this sum the Council has promised to contribute $£ 100$ annually for the seven years, and it appeals, through the three Trustees appointed for the purpose, for assistance in raising the balance required. The cattle herd, which has been enclosed for many centuries, now consists of forty-four animals. It has always been left to follow its own devices, so that annually a master bull fights his way to supremacy, and the retiral of the cows to calve in the woods, where they eonceal their young for nearly a fortnight, recalls the habits of the wild extinct ox, or urus, which inhabited prehistoric Britain. The cattle are so wild as to be unapproachable, but arrangements have been made whereby subscribers to the fund may have entry to the Castle grounds and access to a safe place from which the herd may be viewed. Donations or annual subscriptions should be sent to the Secretary, Zoological Society, Regent's Park, London, N.W.8, marked "Chillingham Cattle Fund".

\section{Future Methods of Charging for Electric Supply}

Sir John Brooke, vice-chairman of the Electricity Commissioners, at a conference on electric light in architecture, organised for architects by the Lighting Service Bureau, gave an interesting address on the future charges for electricity in London. He pointed out that the aim of the Commissioners is to secure a reasonable uniformity of charge. They have chosen as a basis the-two-part tariff-frequently known as the telephone system. The fixed charge is based on the floor area that has to be lighted, and they have devised a scheme for calculating this area. They suggest alternative schemès based either on the number of rooms or the rateable value of the house. In addition to the fixed charge, there is a low running charge made for the energy consumed, which is registered by the meter. He said that the tariff was not popular at first and was not generally accepted. Business men accustomed to dealing with problems of overhead charges and running costs considered it perfectly equitable that everyone who has electricity on tap should pay, in the first place, his share of the capital charges. In five years' time there will be everywhere available - if not compulsory-a two-part tariff. This is of great importance, because in considering the relative costs between minimum lighting, adequate lighting, and that generous scale we should call proper lighting, we have only to reckon on the additional running cost per unit. In the future these additional units will not cost $4 d$., $6 d$., or $8 d$., but will cost $\frac{1}{2} d$., Id., or $1 \frac{1}{2} d$. The reasonable anticipation that tariffs of this nature will be available in a few years' time, with a steady tendency to reduce the running charge to $\frac{1}{2} d$. a unit, as it is in several districts in the neighbourhood of London, will obviously popularise the use of electricity for many purposes from the radio receiver to the vacuum cleaner, and make necessary the introduction of many outlet points when designing the electric wiring of a house.

\section{Institution of Mechanical Engineers}

THE Report of the Council of the Institution of Mechanical Engineers for 1931 states that the total membership of the Institution now stands at 11,161 , an increase of 155 on that of 1930 . The losses by death numbered 103, among the deceased members being Prof. Archibald Barr, Sir Trevor Dawson, Sir Charles Parsons, Sir A. J. C. Ross, and Sir Thomas Stanton. There are now eight branches of the Institution in the provinces and one in South America, and four graduates' sections, all of which have their own programmes of papers. Research work is being continued on alloys, cutting tools, marine engine trials, welding, wire ropes, and other subjects. The Institution has representatives on many boards and committees, including the Royal Society's committee for founding a memorial to the late Sir Charles Parsons. A large number of candidates were examined in England, Scotland, and Ireland for the national certificates and diplomas in mechanical engineering, and the first diplomas were issued for officers of the Royal Air Force, the examination being held in conjunction with the Board of Education and Air Ministry. The Report contains particulars of the awards made for papers read, full details of the finances of the Institution, and records the receipt of gifts, which include a replica of the memorial tablet to George Stephenson at Wylam,

No. 3256, VoL. 129] 
a portrait of the late Sir John Thornycroft, and a commemoration medal of the late Prof. Auguste Rateau.

\section{Standardisation of Electric Frequency in Paris}

ONE of the difficulties in connexion with the nationalisation of the British system of electric supply is the fact that many large systems are using a different frequency of supply from the chosen standard of 50 . The discussion, therefore, on the standardisation of the frequency of electricity supply in Paris, held at the Institution of Electrical Engineers on Feb. 29, was a timely one. P. Rieunier exhibited a film which showed clearly how rapid the conversion had been. The Paris area extends in a circle of about thirty miles in radius around Paris. Before the War it was supplied at four different frequencies by various undertakings. In 1919 it was decided to build large modern steam-generating stations in Paris and connect them with a 60 kilovolt ring main around the city, which was also connected by transformers to the hydro-electric stations of the Central Plateau through the $120 \mathrm{kv}$. and $220 \mathrm{kv}$. mains. In addition, it was decided to create a national network at a frequency of 50 which could be converted into direct current at the highest possible voltage for the electrification of the railways. Instead of having a grid round the country as in England, connected with large and efficient generating stations, France has a series of lines radiating from the principal centres of consumption. In Paris the conversion of the two-phase to direct current is carried out by rotary converters and mercury arc rectifiers. On the 25 frequency network all motors are replaced either by new or second-hand motors having twice as many poles. On the $41 \frac{2}{3}$ frequency network the motors have been unchanged, but the mechanical units to which they are coupled have been adapted to work at a 20 per cent increase of frequency. Luckily the motors were originally manufactured in 50 frequency frames, so it was only necessary to speed them up to the figure for which they were originally designed. Difficulty was experienced in converting small motors such as those used for calculating machines and similar apparatus.

\section{Books for the Blind in the United States}

THE Report of the Library of Congress, Washington, D.C., for the year ending June 30, 1931, is a volume of 463 pages, which includes a review of the activities of its various divisions and gives much interesting information regarding the books and manuscripts acquired during the previous twelve months. The total number of books and pamphlets is now 4,292,288, as against 4,103,936 in June 1930 . "A new responsibility imposed upon us by legislation at the last session", says the report, "concerns the supply of books (in embossed type) for the blind." It is embodied in an Act approved on March 3, 1930, which makes an appropriation of 100,000 dollars to provide books for the use of adult blind residents of the United States. For some time past the Library has done notable work for the blind, and now has a collection of 22,655 books, periodicals, music, etc., mainly in Braille. During the year 1930-31 there were 3359 registered borrowers and 52,222 issues of books, etc. Of this number, 39,330 were works of fiction, 2758 histories, 2444 biographies, and 739 scientific works. With the American National Red Cross, the Library of Congress maintains a Braille transcribing service for the production of Braille manuseript. Lessons are arranged for, certificates of competency are granted, and manuscripts are prepared, bound, and distributed. During 1930-31, 247,708 pages of Braille were completed and, in book form, distributed among 53 institutions, libraries, and individuals. The students helped represented 34 colleges, high schools, and universities, and assistance was given to persons engaged in many callings. But great as is the service rendered, still more is required, and "no private gifts or public funds yet in sight can meet all the growing needs of touch readers"

\section{Biochemical Research in India}

THE Society of Biological Chemists in India, recently founded by the enterprise of certain members of the Department of Biochemistry of the Indian Institute of Science, Bangalore, has published a review of work carried out in India during 1930 ("Biochemical and Allied Research in India in 1930": Society of Biological Chemists, India). The Society was founded to co-ordinate the work carricd out in various parts of the country, and to arrange for the holding of meetings either of members of the Society alone or in association with other societies, for the exchange of ideas and the reading of papers. At present it is not proposed to issue a journal, although this may be practicable in the future as the volume of biochemical research increases. The present review, a pamphlet of twenty pages, deals with work on enzymes and fermentation, agricultural, dairy, plant, animal, and pharmaceutical and medicinal chemistry, nutrition and bacteriology. Reference is made to nearly a hundred original papers published during the year, which incidentally was the first working year of the new Imperial Council of Agricultural Research. The important work carried out by Chopra and his collaborators at the School of Tropical Medicine and Hygiene in Calcutta on the chemistry of Indian drugs, and by McCarrison at the Pasteur Institute, Coonoor, on nutritional problems is referred to, and the hope is expressed that workers will soon be attracted to the field of chemical and biological assay of drugs. The review indicates the rich field for research awaiting the attention of biochemists and pharmacologists in India.

\section{The Epithalassa of the Strait of Georgia}

These conditions have been described by $A$. Hutchinson and C. C. Lucas (Can. J. Research, vol. 5, 1931, 231-284). The Strait of Georgia is a great basin connected with the sea by narrow passages which receive water from a number of large rivers, notably the Fraser River. The water from the latter is conserved during the summer and forms a marked upper layer, the epithalassa, which is characterised by low salinity and high temperature. The tempera. ture may be as much as $10^{\circ} \mathrm{C}$. above the water of the sea. Throughout the greater part of the region this epithalassa has a stability which is sufficient to 